\title{
The Future of Standard Form Contracts in South Africa with Particular Reference to Recent Developments in the Law
}

\author{
Jean Chrysostome Kanamugire \\ Lecturer, Faculty of Law, North West University \\ Email: jean.kanamugire@nwu.ac.za, kajec1@yahoo.co.uk
}

Doi:10.5901/mjss.2013.v4n13p335

\begin{abstract}
Standard form contracts are drafted in advance by the supplier of goods or services and presented to the consumer on a takeit-or-leave-it basis. The consumer's only choice is to adhere to, or refuse to adhere to, the terms of the standard form contracts. They have various advantages for both contracting parties such as cost saving and uniformity. They also have some disadvantages as they are one-sided against consumers and impose unfair terms to the contracting party. Once a contract is signed, it must be honoured. However, public policy can be used to rescue the person from greatly unfair obligations that arise from the contracts. Public policy derives from the Constitution and the fundamental values it enshrines. Consequently, a contractual term that violates the Constitution is contrary to public policy and unenforceable. The Consumer Protection Act (CPA) has a significant impact on standard form contracts. It imposes a duty on the supplier to draw the attention of the customer to the exemption clauses or other contractual terms that oust common law protection. However, the CPA applies only to transactions between suppliers and consumers. The prohibition of unfair, unreasonable or unjust contract terms should apply to every contract. Parliament should intervene and enact legislation to prevent the abuse of freedom of contract by the strong party, to the detriment of other contracting party.
\end{abstract}

Keywords: Standard form contracts, contractual freedom, unfair terms, public policy.

\section{Introduction}

Standard form contracts are defined as "contracts that are drafted in advance by the supplier of goods or services and presented to the consumer on a take-it-or-leave-it basis, thus eliminating opportunity for arm's length negotiation". ${ }^{1}$ They are often used by business persons, such as banks or insurance companies, to contract with individuals or other juristic persons. They provide various advantages to both contracting parties. ${ }^{2}$ The company consults with its legal advisors on the drafting of only one contract that is used for all its transactions. Hopkins argues that "standard form contracts make economic sense: the terms and conditions of trade in many industries are usually well-established prior to the contract being concluded". ${ }^{3}$ This allows "certainty and predictability"4 in the transactions and facilitates contracting parties to make up their minds.

However, standard form contracts have some disadvantages. They are drafted by a legal advisor on behalf of the company. As Hopkins points out, "the draftsman is thus concerned with incorporating all the terms beneficial to the company - usually to the detriment of the consumer". ${ }^{5}$ Such contracts contain unfair terms that are imposed on the consumer, without the possibility of negotiation with the supplier. The consumer simply signs standard form contracts without understanding, and agreeing to, its terms.

When a person contracts with another and signs a document, he or she is usually bound by the terms appearing

\footnotetext{
${ }^{1}$ Barkuizen v Napier 20075 SA 323 (CC), para 135 as per Sachs J; M Nortje "Of reliance, self-reliance and caveat subscriptor" (2012) 129 SALJ 132, 139; RD Sharrock "Judicial control of unfair contract terms: the implications of Consumer Protection Act" (2010) 22 SA Merc LJ 295, 296; HR Hahlo "Buying a new motor car - an object lesson in standard form contracts" (1956) 73 SALJ 443; H Collins "Legal responses to the standard form contract of employment" (2007) 36 ILJ 2, 3.

$2 \mathrm{~K}$ Hopkins "Standard form contracts and the evolving idea of private law justice: a case of democratic capitalist justice versus natural justice" (2003) 1 TSAR 150, 154.

3 Ibid 153.

4 Ibid 154.

5 Ibid; K Hopkins "Insurance policies and the Bill of Rights: rethinking the sanctity of contract paradigm" (2002) 119 SALJ 155.
} 
above his or her signature, even if he or she does not read the entire contract. ${ }^{6}$ The person can find himself or herself in a situation in which he or she has to comply with the contract that he or she did not really consent to. Public policy favours the uttermost freedom of contract. However, it can be used to set aside a contract and rescue one of the contracting parties from his or her obligations. ${ }^{7}$ Public policy "must now be determined by reference to the values that underlie our constitutional democracy as given expression by the provisions of the Bills of Rights". ${ }^{8}$ Accordingly, "a term in a contract that is inimical to the values enshrined in our Constitution ${ }^{9}$ is contrary to public policy and is, therefore, invalid". ${ }^{10}$ Common law already recognises that contracts contrary to public policy are unenforceable. ${ }^{11}$ This even applies to standard form contracts.

Sachs $\mathrm{J}$ has scrutinised standard form contracts in his minority judgment in Barkuizen v Napier. ${ }^{12}$ He recognised that these contracts disguise or undermine freedom of contract between contracting parties. More often, in such contracts, the consumers sign the lengthy contract without really knowing its content. The Consumer Protection Act ${ }^{13}$ has introduced measures to ensure that consumers and suppliers of goods and services reach a genuine agreement in their commercial transactions. The present article examines some important contractual principles, the concept of standard form contracts, their advantages and disadvantages. It also considers public policy in standard form contracts, Sachs' dissenting judgment in the Barkuizen case and the impact of the Consumer Protection Act.

\section{Some Important Contractual Principles}

\subsection{There must be agreement between the parties}

In order to decide whether a contract exists, there must be an agreement between two or more parties. ${ }^{14}$ Agreement by consent, or meeting of the minds (consensus ad idem), is the foundation of the contract. ${ }^{15}$ Therefore, if the minds of the parties do not meet, there is no valid contract. In Cinema City (Pty) Ltd v Morgenstern Family Estates (Pty) Ltd and Others, ${ }^{16}$ Jansen JA observed that "as the generally accepted view is that our law of contract is (save in exceptional cases) based on real consensus, it is fully consonant with basic principles that in matters of interpretation the common intention of the parties should prevail". ${ }^{17}$ The court ascertains whether or not the contracting parties have reached a real agreement.

However, it is not possible to consider what is actually going on in someone's mind. So, for a contract to exist, there must be evidence to prove that the minds of the parties have met. Wessels points out that, "although the minds of the parties must come together, courts of law can only judge from external facts whether this has or has not occurred. In practice, therefore, it is the manifestation of their wills and not the unexpressed will which is of importance". 18 Therefore, if the parties record their agreement in a written document and sign it, this document will indicate what their intention is.

\subsection{Principle of caveat subscriptor}

The caveat subscriptor rule means "let the signer beware". ${ }^{19}$ In terms of this rule, a party who signs a written contract is

\footnotetext{
${ }^{6}$ George v Fairmead (Pty) Ltd 19582 SA 465 (A).

${ }^{7}$ Saskin (Pty) Ltd) v Beukes 19891 SA 1 (A).

8 Barkuizen v Napier (note 1 above) para 29.

${ }^{9}$ Constitution of the Republic of South Africa, 1996.

${ }^{10}$ Barkuizen v Napier (note 1 above) para 29.

11 Hopkins (note 2 above) 159; Saskin (PtY) Ltd) v Beukes 19891 SA 1 (A); M Kruger "The role of public policy in the law of contract, revisited" (2011) 128 SALJ 712.

12 Barkuizen v Napier (note 1 above).

${ }^{13}$ Consumer Protection Act 68 of 2008.

${ }^{14} \mathrm{RH}$ Christie The law of contract in South Africa $5^{\text {th }}$ ed. (2006) 21.

$15 \mathrm{Ibid} 22$

${ }^{16}$ Cinema City Pty Ltd v Morgenstern Family Estates Pty Ltd and Others 19801 SA 796 (A).

17 Ibid 804 D-E; see also Joubert v Enslin 1910 AD 6, 37-38.

${ }_{18}$ Christie (note 14 above) 22; Jordaan v Trollip 1960 PH A25 (T).

${ }_{19}$ Christie (note 14 above) 174 - 176; M Nortje "'Unexpected terms' and caveat subscriptor" (2011) 128 SALJ 741 - 742; CJ Pretorius "Mistake and suretyship: avoiding the spectre of Brink v Humphries \& Jewell (Pty) Ltd" 2009 Obiter 763 - 764; C Lewis "Caveat subscriptor and the doctrine of justus error" (1987) 104 SALJ 371, 375; CJ Pretorius "The basis and underpinnings of the caveat subscriptor rule" 2008 THRHR 660.
} 
bound by the terms of that contract, even if he or she was unaware of the terms of the contract. ${ }^{20}$ In George $v$ Fairmead (Pty) $L t d,{ }^{21}$ the court held that "when a man is asked to put his signature to a document he cannot fail to realise that he is called upon to signify, by doing so, he assents to whatever words appear above his signature". 22 Innes, CJ accepted that this condition was hard and onerous; but he pointed out that if people signed such conditions they had to be held to them, unless they could show that there was fraud involved..$^{23}$ Therefore individuals should take reasonable steps to ascertain the meaning of the contract before they sign the agreement.

Turpin points out that the reason why the signatory is bound is because he or she creates the impression in the mind of the other party that he or she is agreeing to the contract. ${ }^{24}$ Therefore, the signatory is liable whether or not he or she read the document or knew of its contents ${ }^{25}$ and even though unable to read, ${ }^{26}$ or ignorant of the legal meaning of the document. ${ }^{27}$ The effect of the caveat subscriptor rule is that "a party who has signed a standard form contract will be bound to all terms of that contract, no matter how onerous, unreasonable or unexpected such terms may be". ${ }^{28}$ It is not easy for a person to rebut this principle.

There are exceptions to this general principle of caveat subscriptor. ${ }^{29}$ These exceptions include fraud, undue influence and duress and if the signatory can show that it is not reasonable for the other person to believe that he or she was agreeing to the contract. Nevertheless it is not easy for a signatory to get out of a contract. The principle which underlies this is known as pacta sunt servanda.

\subsection{Sanctity of contracts (pacta sunt servanda)}

All parties have the right to freely enter into contracts. The expression

'freedom of contract' has four aspects: firstly, and primarily, freedom from interference by the state or its officials to negotiate the terms of a contract, and the corrective freedom from having them imposed on one; secondly, freedom to select the person with whom one contracts; thirdly, freedom not to contract; and, finally, freedom from having a contract one has made being interfered with. 30

The doctrine of freedom of contract is based on the premise that both contracting parties hold a position of equal bargaining strength and that they are free to accept or reject any terms of the contract. ${ }^{31}$ It ensures that "courts will not lightly interfere with contractual provisions agreed to between the parties, however harsh they may be". ${ }^{32}$ Freedom of contract requires that "men of full age and competent understanding shall have the utmost liberty of contracting, and that their contracts, when entered into freely and voluntarily, shall be held sacred and shall be enforced by courts of justice". 33 Contracts must be honoured in all circumstances.

In Burger v Central South African Railways, ${ }^{34}$ Innes CJ stated that "our law does not recognise the right of a court to release a contracting party from the consequences of an agreement duly entered into by him merely because that agreement appears to be unreasonable". ${ }^{35}$ In Tjollo Ateljees (Eins) Bpk v Small, ${ }^{36}$ van der Heever JA emphasised the freedom of contract by saying "in my opinion the doctrine that persons of full legal capacity can resile from a contract into

20 S Cornelius "The writing is on the wall for small print" (2001) 4 TSAR 793; CC Turpin "Contract and imposed terms" (1956) 73 SALJ 144, 149 - 152.

${ }^{21}$ George v Fairmead (Pty) Ltd 19582 SA 465 (A).

22 Ibid 472A; Burger v Central South African Railways 1903 TS 571, 578.

23 Wells v South African Alumenite Co 1927 AD 69, 73.

24 Turpin (note 20 above) 149-150.

25 Geodhals v Massey-Harris \& Co 1939 EDL 314.

${ }^{26}$ Bhikhagee v Southern Aviation (Pty) Ltd 19494 SA 105 (E).

${ }^{27}$ Mathole v Mathole 19511 SA 256 (T).

${ }^{28}$ Cornelius (note 20 above) 793.

${ }^{29}$ Burger v Central South African Railways 1903 TS 571, 578.

${ }^{30} \mathrm{E}$ Kahn et al Contract and mercantile law a source book $2^{\text {nd }}$ ed. Vol. 1 (1988) 32 - 33.

$31 \mathrm{~K}$ Alheit "Contractual liability arising from the use of computer software: notes on the different positions of parties in Anglo-American law and South African law" (2000) 23 CILSA 26, 28.

$32 \mathrm{lbid}$.

33 Wells v South African Alumenite Co (note 23) 73.

34 Burger v Central South African Railways 1903 TS 571.

35 Ibid 576; HR Hahlo "Unfair contractual terms in civil law system" (1981) 98 SALJ 70.

36 Tjollo Ateljees (Eins) Bpk v Small 19491 SA 856 (A). 
which they have solemnly entered in the absence of fraud, duress or excusable mistake, was never part of the law of South Africa, and in the few cases in which it was applied, it was done so by mistake". ${ }^{77}$ Parties who have freely and voluntarily entered into a standard form contract must respect their agreement or commitment.

The doctrine of sanctity of contracts requires that the minds of the contracting parties must meet in relation to all the terms of the contract. With regard to consensuality, "there are two cordial rules that must be satisfied in order for a party to be bound by terms imposed by means of a standard contract or other notification". ${ }^{38}$ First, notification of the terms must have been contemporaneous with the contract. ${ }^{39}$ Secondly, the consumer must have either actual or constructive knowledge of the terms; in the absence of express personal notification, the courts have insisted that the circumstances must have been such that a reasonable man would have become aware of the terms. ${ }^{40}$ If these prerequisites are complied with, then the parties must honour their contracts.

Ngcobo $\mathrm{J}$ has recognised the maxim of pacta sunt servanda as a necessary principle in the South African law of contract. ${ }^{41}$ In general, "parties should comply with contractual obligations that have been freely and voluntarily undertaken". ${ }^{42}$ He stated that the maxim gives effect to the central constitutional values of freedom and dignity. In addition, he pointed out that "self-autonomy, or the ability to regulate one's own affairs, even to one's own detriment, is the very essence of the freedom and a vital party of dignity". ${ }^{33}$ The doctrine of pacta sunt servanda ensures that courts employ the constitutional values to achieve a balance that strikes down the unacceptable excess of freedom of contract, while seeking to permit individuals' dignity and autonomy in regulating their own lives. ${ }^{44}$ Intruding on apparently voluntarily concluded arrangements is a step that judges should countenance with care, particularly when it requires them to impose their individual arrangements. ${ }^{45}$ Therefore, pacta sunt servanda is an important principle in South African law of contract. However, the courts will not enforce contracts or contractual terms which are contrary to public policy.

\subsection{Public policy}

Public policy46 recognizes the sanctity of contract. In Wells $v$ South African Alumenite Co, ${ }^{47}$ Innes CJ observed that "if there is anything which, more than another, public policy requires, it is that men of full age and competent understanding shall have the utmost liberty of contracting, and that their contacts, when entered into freely and voluntarily, shall be held sacred and shall be enforced by courts of justice." ${ }^{8}$ Public policy demands, in general, full freedom of contract, and the right of men freely to bind themselves in respect of all legitimate subject-matters. ${ }^{49}$ Another important consideration is that public policy should properly take into account the doing of justice between person and person. ${ }^{50}$

As a general principle, agreements that are contrary to public policy will not be enforced. ${ }^{51}$ The interests of the community or the public are of paramount importance in relation to the concept of public policy. As a result, agreements that are clearly inimical to the interests of the community, whether they are contrary to law or morality, or run counter to social or economic expedience, will accordingly, on the grounds of public policy, not be enforced. ${ }^{52}$ In Brisley v Drotky,

\footnotetext{
37 Ibid 871.

38 JR Harker "Imposed terms in standard form contracts" (1981) 98 SALJ 15, 18.

39 Ibid; Peard v Rennie \& Sons (1895) 16 NLR 175; W J Lineveldt (Edms) Bpk v Immelman 19802 SA 964 (O) $966 \mathrm{H}$ - $967 \mathrm{C}$.

40 Harker (note 38 above) 18; Smith v Carson 1916 EDL 26, Central South African Railways v Mc Laren 1903 TS 727, Frocks Ltd v Det and Goodwin (Pty) Ltd 19502 SA 717 (C), Minor Shipping (Pty) Ltd v Treger Golf and Sports (Pty) Ltd 19772 SA 709 (W).

${ }^{41}$ Barkuizen v Napier (note 1 above) para 57. See also PJ Sutherland "Ensuring contractual fairness in consumer contracts after Barkuizen v Napier 20075 SA 323 (CC) Part 2" (2009) 20 Stell LR 50, 50 - 53.

${ }^{42}$ Barkuizen v Napier (note 1 above) para 57; Napier v Barkuizen 20064 SA 1 (SCA) para 12; Brisley v Drotsky 20024 SA 1 (SCA) para 94; and Afrox Healthcare (Bpk) v Strydom 20026 SA 21 (SCA) para 12.

43 Barkuizen v Napier (note 1 above) para 57.

44 Ibid para 70.

$45 \mathrm{lbid}$.

46 PJ Sutherland "Ensuring contractual fairness in consumer contracts after Barkuizen v Napier 20075 SA 323 (CC) Part 1" (2008) 19 Stell LR 390, 406 - 407; FDJ Brand "The role of good faith, equity and fairness in the South African law of contract: the influence of the common law and constitution" (2009) 126 SALJ 70, 74 - 89.

47 Wells v South African Alumenite Co (note 23 above).

48 Ibid 73, Barkuizen v Napier (note 1 above) paras 57 and 70.

${ }^{49}$ Sasfin (Pty) Ltd v Beukes (note 7 above) 9H; Printing and Numerical Registration Co v Sampson [1897] LR 19 Eq $462,465$.

50 Jajbhay v Cassiem 1939 AD 537, 544.

51 Sasfin (Pty) Ltd v Beukes (note 7 above); Kruger (note 11 above) 715.

52 Sasfin (Pty) Ltd v Beukes (note 7 above) 1 - 2; Barkuizen v Napier (note 1 above) para 158.
} 
Cameron JA held that "public policy is now rooted in our Constitution and the fundamental values it enshrines". ${ }^{53}$ They include human dignity, the achievement of equality and the advancement of human rights and freedom, non-racial and non-sexism. ${ }^{54}$ The contractual terms that violate the values of the Constitution are invalid and not enforceable as they are contrary to public policy.

In Barkuizen v Napier, Ngcobo J held that public policy had to be determined with reference to the Constitution, so that a contractual term that violated the Constitution was, by definition, contrary to public policy and therefore unenforceable. ${ }^{55} \mathrm{He}$ added that the proper approach to constitutional challenges to contractual terms was to determine whether the term challenged was contrary to public policy as evidenced by the constitutional values, in particular, those found in the Bill of Rights. ${ }^{56}$ This approach recognised the operation of the doctrine of pacta sunt servanda and, at the same time, allowed courts to decline to enforce contracts that were contrary to the constitutional values, even though the parties might have consented to them. ${ }^{57}$ Therefore contracting parties should comply with the provisions of the Constitution in every contract they make.

In the same case, Ngcobo J has introduced a two-stage test when dealing with public policy. The first enquiry must be directed at the objective terms of the contract. ${ }^{58}$ If they are contrary to public policy, the courts will not uphold the terms. However, if it is found that the objective terms are not inconsistent with public policy on their face, the further question will then arise which is whether the terms are contrary to public policy, in the light of the relative situation of the contracting parties. ${ }^{59} \mathrm{He}$ acknowledged that unequal bargaining power was one of the factors that played a role in the consideration of public policy. ${ }^{60}$ Cameron J, in Napier v Barkuizen, also recognized that unequal bargaining power could well be a factor in striking down a contract on public policy and thus constitutional grounds. ${ }^{61}$ The inequality of bargaining power may cause potential injustice among contracting parties. The next section deals with the concept of a standard form contract.

\section{Understanding the Concept of the Standard Form Contracts}

Aranstam states that "the term 'standard form contract' has three possible meanings". ${ }^{2}$ First, it denotes precedents of contracts in the guise of model specimen forms, to which a person may refer if he or she has to draft a contract. ${ }^{63}$ Second, 'it ceases to represent the outcome of ad hoc bargaining between the parties'. ${ }^{64}$ For instance, once the contract has been concluded, the rights and duties of the parties are defined before contracting takes place. In fact, there is no record of the actual facts surrounding the formulation and performance of each agreement or of the particular needs of the consumer. ${ }^{65}$ This type of agreement is presented by the party who wishes to contract on its terms to another on a 'take-it-or-leave-it' basis. ${ }^{66}$ Lastly, the third type of standard form contract consists of those in which certain terms in the contract are imposed by statute, either leaving the rest of the contract to be negotiated freely by the parties themselves, or permitting one party to impose the residual terms on the other, if he or she can get away with it, in an adhesion type contract. 67

The type of agreement, presented by the party who wishes to contract on its terms to another on a 'take-it-orleave-it' basis, is often referred to as a contract of adhesion. ${ }^{68}$ This term was coined or created by a French jurist, Raymond Saleilles, to describe those agreements in which the conditions of the contract are fixed by one party, before

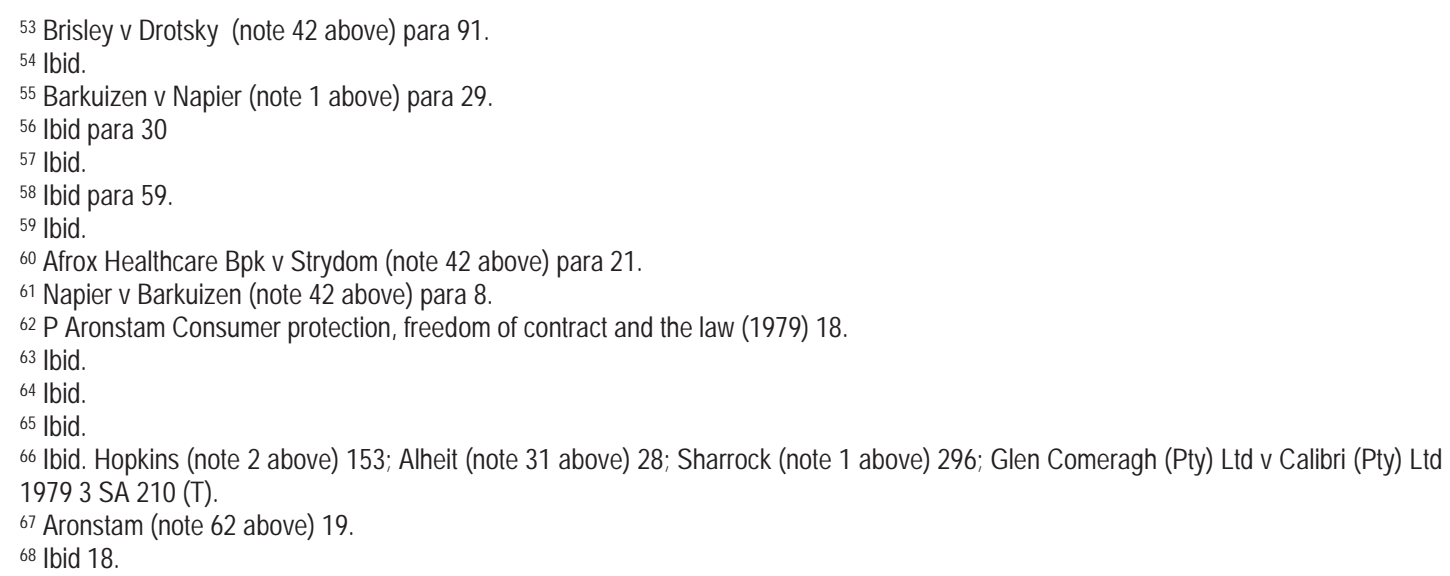


the conclusion of the agreement. ${ }^{69}$ The other party's bargaining power is severely limited. If the contract is to be accepted, it has to be accepted in this form, and its terms are not open to discussion. ${ }^{70}$ Soleilles points out that a standard form agreement cannot be regarded as a contract in the true sense of the word, because it has been forced on one of the parties and if that party wants to enter into the agreement he or she simply has to accept the terms of the contract without any argument. ${ }^{71}$

The term "adhesion contract" is encountered in Anglo-American law, but it has not been adopted in South Africa. Instead, South African law uses the more common term of Anglo-American law, "standard form contract". ${ }^{72}$ According to history, especially in the carriage of goods by sea and insurance, the standard form contract was used for the carrying of pilgrims to the Holy Land in the twelfth and thirteenth centuries. However, it became widespread only in the latter part of the nineteenth century. ${ }^{73}$ Today standard form contracts are found in almost all economic activities such as mortgage bonds, insurance policies, charterparties, bills of lading, sales on instalments (credits sale agreements), suretyships, sales and leases of motor cars, contracts of dry-cleaners, contracts of nursing homes, sales of computer software, and so on. ${ }^{74}$ Most people enter into standard form contracts in their commercial transactions on a daily basis. It is very seldom that an ordinary consumer will enter into a commercial contract which is drafted "from scratch", taking into considerations the concerns of both contracting parties.

Sales defines "standard form contracts" to "include every contract, whether simple or under seal and whether contained in one or more documents, one of the parties to which habitually makes contracts of the same type in a particular form and will allow little, if any, variation from that form" ${ }^{75}$ According to Rakoff, ${ }^{76}$ seven characteristics define a model contract of adhesion. These are:

(1) The document whose legal validity is at issue is a printed form that contains many terms and clearly purports to be contract.

(2) The form has been drafted by, or on behalf of, one party to the transaction.

(3) The drafting party participates in numerous transactions as a matter of routine.

(4) The form is presented to the adhering party with the representation that the drafting party will enter into the transaction only on the terms contained in the document.

(5) After the parties have dickered over whatever terms are open to bargaining, the document is signed by the adherent.

(6) In comparison with the drafting party, the adhering party enters into few transactions of the type represented by the form.

(7) Payment of money is the principal obligation of the adhering party in the transaction. ${ }^{77}$

Standard form contracts have important advantages for both parties that participate in commercial transactions.

\section{Advantages of Standard Form Contracts}

Standard form contracts are an important part of everyday commercial life. ${ }^{78}$ Although they have been a part of commercial transactions for many years, the development of standard form contracts, as an indispensable part of commercial life, really only developed in the twentieth century. ${ }^{79}$ This is due to a very considerable increase in largescale economic activity, which means that standardisation is unavoidable. ${ }^{80}$ The advantages of standard form contracts may be summarised as follows:

- cost saving,

${ }^{69}$ Strictly, a contract of adhesion means one that does not admit the possibility of negotiation, such as contract of carriage by air. See Kahn (note 30 above) 33.

${ }^{70}$ Aranstam (note 62 above) 18.

${ }^{71} \mathrm{lbid}$.

${ }^{72}$ Kahn (note 30 above) 33.

$73 \mathrm{lbid}$.

74 Ibid 33-34.

${ }^{75}$ HB Sales "Standard-form contracts" (1953) 16 Modern LR 318. See also CH Bright 'Contracts of adhesion and exemption clauses' (1967) 41 Australian LJ 261, 265.

${ }_{76}$ TD Rakoff "Contracts of adhesion: an essay in reconstruction" (1983) 96 Harvard LR 1173.

77 Ibid 1177.

${ }^{78}$ Cornelius (note 20 above) 793.

${ }^{79}$ Harker (note 38 above) 16 .

80 Ibid; see also C Grunfeld 'Reform in the law of contract' (1961) 24 Modern LR 62, 64. 
- greater certainty,

- uniformity and

- $\quad$ easy altering. ${ }^{81}$

\subsection{Cost saving}

An important advantage of using standard form contracts is that they reduce the cost of entering into contracts, because a full set of terms is available to the contracting parties when they need to draft their contracts. ${ }^{82}$ Aronstam points out that once a standard form agreement has been properly drafted, it can be used repeatedly and so it is not necessary for the parties to employ the services of legal advisers. ${ }^{83}$ The standard form contract that is well drafted can clarify the legal relations between contracting parties. In this way, it reduces the prospect of litigation, allows more accurate calculation of risks, and gives confidence to lay persons untrained in law. ${ }^{84}$ Commenting on the advantages of standard form contracts, Wilson writes:

Preoccupation with the evils of standardised contracts from the point of view of the offeree must not allow their admitted virtues to be overlooked. By saving time and trouble in bargaining, simplifying internal administration and facilitating planning, they reduce administrative costs to an extent which must benefit both parties. They have, it is said, a lulling effect induced by the knowledge that one is signing "what everyone else has signed". They also reduce risk to a calculable quantity and, perhaps most important of all, have the potential, if drawn up in an enlightened manner, of becoming "a wise code governing intra- or extra-trade relations of a business group". 85

Furthermore, "the printed forms permit senior management of a firm to control the contractual arrangement made by subordinate sales staff". ${ }^{86}$ The current orderly method in the distribution of goods and services that has become standardised in a mass consumer market requires the use of standard form contracts. ${ }^{87}$ This is the reason why trade organisations often decide that contracts between their members or with outsiders must be on the standard form. ${ }^{88} \mathrm{It}$ drastically reduces the cost of making and controlling the business.

Hopkins argues that the cost saving advantage is one of the most obvious advantages of using standard form contracts. ${ }^{89}$ The supplier only has to consult with its legal advisors in order to draft one contract. This contract can now be used for all or most of its commercial activities or transactions. ${ }^{90}$ This allows the suppliers to make numerous transactions on a daily basis without having to sit down with every purchaser and negotiate a new contract from scratch.

\subsection{Greater certainty}

Standard form contracts "may lead to greater certainty in legal relations, in that once the terms of standard contracts have received the considerations by the courts, they are likely to be interpreted in the same way in future cases". ${ }^{91}$ Sales points out that, according to lawyers, the biggest advantage is that the terms of the greater number of contracts made in the future will be certain, and will be the same in all contracts for similar transactions..$^{92}$ Once the company has employed the skills and services of a legal advisor to draft the contract, most contingencies become accounted for in the document. ${ }^{93}$ This usually enables the company to incorporate terms into the contract that will effectively minimise business risks. ${ }^{94}$ Thus it may contribute to less litigation in carrying out business activities. Certainty in legal and commercial transactions will also be ensured.

\footnotetext{
81 Sales (note 75 above) 340.

82 Barkuizen v Napier (note 1 above) para 139.

${ }_{83}$ Aronstam (note 62 above) 24; D Yates Exclusions clauses in contracts 2nd ed. (1982) 1-2; Harker (note 38 above) 16.

${ }^{84}$ Kahn (note 30 above) 34.

85 NS Wilson "Freedom of contract and adhesion contracts" (1965) 14 ICLQ 172, 176; Aronstam (note 62 above) 24.

${ }^{86}$ Barkuizen v Napier (note 1 above) para 139.

87 Kahn (note 30 above) 34.

88 Ibid 34. See also Yates (note 83 above) 1-5.

89 Hopkins (note 2 above) 153.

90 Ibid.

91 Harker (note 38 above) 16; Aronstam (note 62 above) 24; Sales (note 75 above) 340 (on the issue of certainty).

92 Sales (note 75 above) 340.

93 Hopkins (note 2 above) 154.

94 Ibid.
} 


\subsection{Uniformity}

Similarity of terms in contracts typically recurring in a business enterprise is an important factor, as it facilitates the exact calculation and allocation of risks. ${ }^{95} \mathrm{~A}$ customer trading with more than one firm using standard form contracts will know that the same form of contract is being used in each transaction. ${ }^{96} \mathrm{He}$ or she may familiarise himself or herself with the terms of the contract. In addition, the trader or business person will benefit from this uniformity, inasmuch as he or she will be saved from the effort of preparing his or her own standard forms, or the lawyers' fees for preparing them for him or her. ${ }^{97}$

\subsection{Easy altering (flexibility)}

A standard form contract can be altered any time that the supplier deems fit to do so. This allows flexibility in business transactions. In a particular trade or business, the standard form contract produced by the supplier "should be so well prepared so that it could, in normal circumstances, last for many years without variation, but whenever an alteration is required it would be a comparatively simple matter to make it." "98 The supplier can, at any time, change the terms of a standard form contract in order to comply with, or accommodate, the changing conditions, or to ensure that specific customer interests are accommodated.

\section{Disadvantages of Standard Form Contracts}

Legal advisors draft or prepare standard form contracts on behalf of a particular business. The result is that the drafter is usually concerned with protecting the interests of the business, rather than protecting the interest of consumers. ${ }^{99} \mathrm{An}$ example is exemptions or limitation clauses which are found in short-term insurance policies. These operate to exclude the liability of the insurer in certain circumstances. ${ }^{100}$ There are two main criticisms of standard form contracts:

- they are one-sided in favour of the business and

- they contain unfair terms.

\subsection{One-sided in favour of the business}

Big organisations which rely on standard form contracts can take advantage of their position. They can usually employ competent legal staffs and acquire the best legal advice. ${ }^{101}$ Hopkins states that, in order to protect their clients 'from all possible contingencies, a document is produced which more often than not exceeds the basic requirements of the company and exploits every possible latitude permitted by law'.102 Consumers have no bargaining power to negotiate the terms of the contracts and they are forced to take-it-or-leave-it on the terms offered. ${ }^{103}$ This significantly affects the consumers in their bargaining power to contract.

In drafting standard form contracts, consumers or any body representing their interests do not contribute their views about the form the contract should take, unless a statute expressly states that they should participate. ${ }^{104}$ In addition, the consumer "is constantly being asked to 'sign on the dotted line' but rarely appreciates the legal consequences of his signature". ${ }^{105}$ The contract does not really represent the agreement between the consumer and the supplier. Slawson points out that "indeed, in the usual case, the consumer never even reads the form, or reads it only

\footnotetext{
95 Yates (note 83 above) 4.

${ }_{96}$ Sales (note 75 above) 340.

97 Ibid.

98 Ibid.

99 Hopkins (note 2 above) 154. K Hopkins "Insurance policies and the Bill of Rights: rethinking the sanctity of contract paradigm" (2002) 119 SALJ 155.

100 Barkuizen v Napier (note 1 above).

101 Sales (note 75 above) 322.

102 Hopkins (note 2 above) 154; S Eiselen \& SK Bergenthal "The battle of forms: a comparative analysis" (2006) 39 CILSA $214,215$.

${ }_{103}$ Hopkins (note 2 above) 154; P Aronstam "Exemption clauses in contracts: a new approach for South African courts" (1977) 94 SALJ 55; Sutherland (note 41 above) 61; S van der Merwe at al Contract general principles $3^{\text {rd }}$ ed (2007) 310.

104 Sales (note 75 above) 322; Van der Merwe (note 103 above) 311.

105 Sales (note 75 above) 333. See also PS Atiyah The rise and fall of freedom of contract (1979) 731.
} 
after he has become bound by its terms". ${ }^{106} \mathrm{He}$ or she only knows the effect or hardship of the standard form contract when he or she tries to enforce it. It is recommended that the consumer must read and ascertain the content or terms of the standard form contract before engaging in any transaction.

\subsection{Imposition of unfair terms}

The main danger of standard form contracts is that they contain unfair terms, particularly exemption or forfeiture terms, and the average consumer is normally ignorant of the meaning of the terms. ${ }^{107}$ The shocking feature of these contracts is that they provide means for a supplier to impose terms, usually designed for his or her own protection, on persons who require his or her goods or services. In fact, the consumers cannot accept these terms if they are free to choose. ${ }^{108} \mathrm{In}$ Western Bank Ltd v Sparta Construction Co, ${ }^{109}$ Coetzee J dealt with a standard lease agreement. He pointed out a number of undesirable features of these printed agreements. He also stated that if the lessee could read and understand the terms of the contract, he might very well not find the agreement, as a whole, acceptable to him..$^{110}$ In addition, the judge argued that the time had come to properly investigate this particular business practice and that legal provisions which were fair to both parties should then be enacted to regulate their peculiar relationships. ${ }^{111}$ Coetzee $\mathrm{J}$ also recommended that a minimum standard of printing and size of print for all printed contracts should be introduced.

In Linstrom v Venter, ${ }^{112}$ Claassen JP said:

The person who is unable to pay cash for a valuable article, such as a motor car, often finds his freedom of contract very limited, because so many trading firms have adopted standard forms of contract which the purchaser has to sign or remain without the article. Theoretically the prospective purchaser is free to offer terms and refuse counter offers, but in practice he usually has to sign the seller's printed form of contract in order to obtain the desired article. Such contracts are designed for the protection of the seller and their terms are often of an oppressive nature.113

The customer has no control over the imposition of unfair terms which deprive him or her of reasonable rights of compensation or otherwise oust the protection of the common law. ${ }^{114}$ Moreover, the supplier will usually not entertain any variation in the terms of the contract. The only freedom left to the customer is the alternative to accepting the terms presented to him/her or not contracting at all. ${ }^{115}$ Therefore standard form contracts have impinged on the freedom of contracting parties to enter into binding agreements or transactions.

In Barkuizen v Napier, ${ }^{116}$ Sachs J observed that standard form contracts "contain a common stock of contract terms that tend to be weighted heavily in favour of the supplier and operate to limit or exclude the consumer's normal contractual rights and the supplier's contractual obligations and liabilities". ${ }^{117}$ These contracts enable suppliers of firms to legislate in a substantially authoritarian manner without using the appearance of authoritarian forms. ${ }^{118}$ The consumer is frequently unable to resist the terms in a standard form contract, and he or she is often unaware of their existence or unable to appreciate their import. ${ }^{119}$ Onerous terms are usually couched in a legal way and incorporated as part of the fine print of the contract.

${ }^{106}$ W D Slawson "Standard form contracts and democratic control of lawmaking power" (1971) 84 Harvard LR 529, 530; Atiyah (note 105 above) 731.

${ }^{107}$ Kahn (note 30 above) 34; Aronstam (note 103 above) 55.

${ }^{108}$ Harker (note 38 above) 16; DJ Woolfrey "Consumer protection - a new jurisprudence in South Africa" (1989 - 1990) 11 Obiter 109, 120.

109 Western Bank Ltd v Sparta Construction Co 19751 SA 839 (W).

$110 \mathrm{lbid} 840$.

111 lbid.

112 Linstrom v Venter 19571 SA 125 (SWA).

113 Ibid 127.

114 Harker (note 38 above) 16-17; see also Aronstam (note 62 above) 25; Turpin (note 20 above) 145.

115 Harker (note 38 above) 17; Aronstam (note 62 above) 20; Woolfrey (note 108 above) 120.

${ }^{116}$ Barkuizen v Napier (note 1 above).

117 Ibid para 135.

${ }^{118}$ Burkuizen v Napier (note 1 above) para 145; A Louw "Employment based on a fiction: evaluating the legitimacy of traditional notions of contract in their application to an atypical employment relationship" (2007) 28 Obiter 187, 226; F Kessler "Contracts of adhesion some thoughts about freedom of contract" (1943) 43 Columbia LR 629, 640.

${ }^{119}$ Barkuizen v Napier (note 1 above) para 135; Bright (note 75 above) 271 (A customer is often not aware of the existence of particular clauses until a dispute arises). 
With regard to the conclusion of standard form contracts, the printed document will usually be signed by both parties, but frequently it is merely handed over or posted at the time of the formation of the contract. ${ }^{120}$ Some doubt has been expressed about the validity of such standard forms to count as contracts at all. They often amount to an imposition of will, rather than mutual consent to an agreement. ${ }^{121}$ These transactions have been described as contracts of adhesion, whereby consumers have no other choice but to adhere to them or not. However, public policy can be used to rescue one of the contracting parties who is subject to harsh conditions in the standard form contract.

\title{
6. Public Policy and Standard Form Contracts
}

The common law does not recognise contracts or agreements that are contrary to public policy. ${ }^{122}$ Where a standard form contract is particularly harsh, the concept of public policy can be used to set it aside. The most obvious example is Sasfin (Pty) Ltd $v$ Beukes. ${ }^{123}$ In this case, the appellant (Sasfin) was a finance company and the respondent (Beukes) was a medical doctor practicising as a specialist anaesthetist. The respondent borrowed money from the applicant. As a security for the loan, the respondent signed a deed of cession in favour of the applicant. According to the deed of cession, he effectively placed the respondent in control of all his professional earnings. ${ }^{124}$ The appellant could recover all the respondent's book debts and retain all amounts so collected, irrespective of whether he was indebted to it in a lesser amount or at all. As a result, the respondent could be effectively deprived of his whole income and means of support for himself and his family. ${ }^{225}$

The respondent was powerless to bring the situation to an end by reason of a provision that the deed of cession would be, and continued to be, of full force and effect until terminated by all creditors. ${ }^{126}$ In the words of Smalberger JA, the respondent was "virtually relegated to the position of a slave, working for the benefit of Sasfin". 127 The court held that the agreement was clearly unconscionable and incompatible with public interest and was therefore contrary to public policy. ${ }^{128}$ The offending provisions were held not to be severable from the remainder of the deed of cession. Therefore, the whole deed of cession was void ab initio. As the deed of cession was against public policy, it could not be enforced. In arriving at this decision, Smalberger JA stated that:

\begin{abstract}
No court should therefore shrink from the duty of declaring a contract contrary to public policy when the occasion so demands. The power to declare contracts contrary to public policy should, however, be exercised sparingly and only in the clearest of cases, lest uncertainty as to the validity of contracts result from an arbitrary and indiscriminate use of the power. One must be careful not to conclude that a contract is contrary to public policy merely because its terms (or some of them) offend one's individual sense of propriety and fairness. ${ }^{129}$
\end{abstract}

In Eastwood v Shepstone, ${ }^{130}$ Innes CJ acknowledged that the court had the power to treat as void, and refuse in any way to recognise, contracts or transactions which were against public policy. However, such power should "not be hastily or rashly exercised". ${ }^{131} \mathrm{He}$ admitted that once it was clear that any arrangement was against public policy, the court would be wanting in its duty if it hesitated to declare such an arrangement void. ${ }^{132}$ For other jurisdiction, such as the United Kingdom, Lord Atkin said that "the doctrine should only be invoked in clear cases in which harm to the public is substantially incontestable, and does not depend upon idiosyncratic inferences of a few judicial minds". 133 "Although the power of the courts to invalidate bargains of parties on grounds of public policy is unquestioned and is clearly necessary,

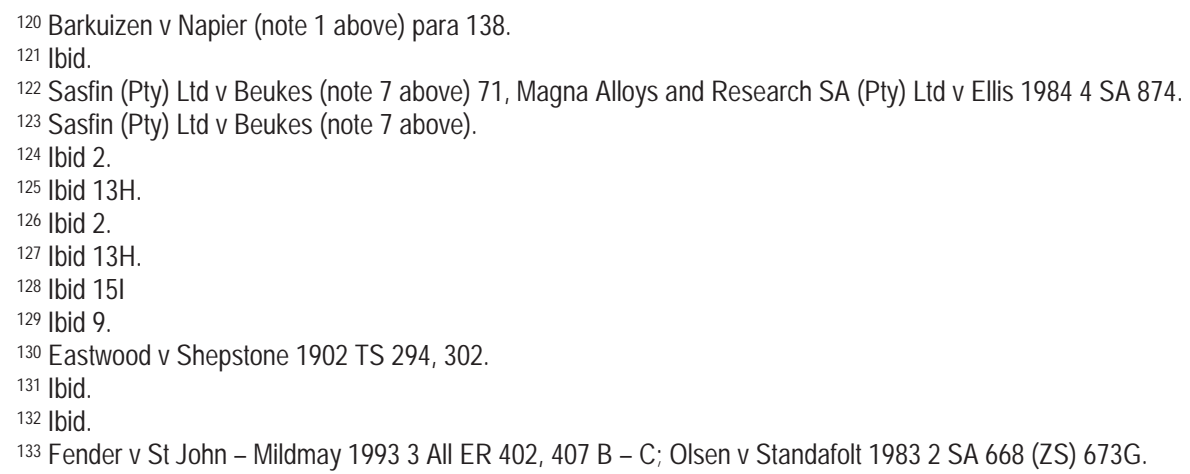


the impropriety of the transaction should be convincingly established in order to justify the exercise of the power". ${ }^{134}$

As stated above, the courts do not readily set aside contracts which have been freely and voluntarily entered into. The principle of pacta sunt servanda still applies and those who sign standard form contracts which they do not necessarily understand will find themselves bound by these contracts. This applies even if the terms of that contract, or some of its terms, are unfair. In Afrox Healthcare Bpk $v$ Strydom, ${ }^{135}$ the respondent went to the hospital and signed a standard form contract that excluded liability for any damages suffered as a result of negligence of nursing staff or employees of the appellant. He suffered damages due to the negligence of the nursing staff. The court held that "the elementary and basic general principle was that it was in the public interest that a contract entered into freely and seriously by parties having the necessary capacity should be enforced". ${ }^{136}$ The court did not support the respondent's contention that a contractual term in terms of which a hospital could exclude liability for the negligent conduct of its nursing staff was not in the public interest. ${ }^{137}$ Here the court did not recognise that the respondent was in a desperate situation of getting medical assistance and was not in a conducive condition to contract. The concept of standard form contract was recently criticised by Sachs $\mathrm{J}$ in his dissenting judgment in Barkuizen v Napier and the Consumer Protection Act has introduced new principles which have an impact on standard form contracts. The present paper has focused on the law as it was in the past. The focus will now shift towards considering these new developments.

\section{Sachs' Dissenting Judgment in Barkuizen v Napier(CC)}

\subsection{Facts}

The applicant was Mr Barkuizen and the respondent was Mr Napier, representing an insurance broking company, Hamford (Pty) Ltd (Hamford). The applicant was at all relevant times insured by Hamford. On 24 November 1999 the applicant's insured motor car (BMW) was involved in an accident. On 2 December 1999, he duly informed the insurer of the event. On 7 January 2000 Hamford repudiated the claim of the applicant in writing. On 8 January 2002 the applicant served the particulars of his claim on Hamford. ${ }^{138}$ The respondent expected to the claim on the ground that there was a time-bar clause contained in their signed contract.

The time-bar had "the effect that if they rejected liability for any claim, they would be released from liability unless summons was served on them within 90 days of repudiation". 139 The Pretoria High Court upheld the application. The respondent successfully appealed to the Supreme Court of Appeals (SCA). The SCA upheld the appeal on the ground that S 34 of the Constitution did not preclude the creation or referral of rights, subject to a time-limit for their enforcement. ${ }^{140}$ In addition, constitutional norms and values could not operate to invalidate the time-bar clause. ${ }^{141}$ The applicant appealed to the Constitutional Court (CC). Sachs J delivered a minority judgment in which he extensively discussed standard form contracts.

Sachs J observed that there were four documents that constituted the agreement between the parties. The fourth document contained 29 pages in small print size. On the fourth page there was a requirement that "notification of an event likely to give rise to a claim must be given as soon as possible and the claim submitted within 30 days". ${ }^{142}$ On the fifth page there were four provisions, including clause 5.2.5, which was the heart of the litigation. This clause reads: "if we reject liability for any claim made under this policy we will be released from liability unless summons is served on Lloyd's

\footnotetext{
134 Sasfin (Pty) Ltd v Beukes (note 7 above) 9 D. See also Eerste Nasionale Band van Suidelike Afrika Bpk v Saayman NO 19974 SA 302 (SCA). In this case, the SCA held that where a surety was obviously physically weak and confused and possibly unable to understand fully the contents of the agreement, or where surety was, to the knowledge of the creditor, the debtor's spouse or elderly parent, public policy required that the creditor ensured that the surety understood the full import of the agreement and of any consequent cessions. This could be achieved by insisting that the surety obtains independent legal advice, or by having the creditor explain to the surety the full implications of the agreement and any related documents (at $304-305$ ). According to public policy, the court refused to enforce the deed of cession.

135 Afrox Healthcare Bpk v Strydom (note 42 above).

136 Ibid 28 F-G.

137 Ibid 28 G-H.

138 Barkuizen v Napier (note 1 above) para 121.

139 Ibid 122.

140 Napier v Barkuizen 20064 SA 1 (SCA) para 26.

141 Ibid para 28.

142 Barkuizen v Napier (note 1 above) para 132.
} 
SA or Hamford (Pty) Ltd within 90 days of repudiation". ${ }^{143}$ It appeared that the parties did not discuss the content of the fourth document but the applicant was aware of its existence. ${ }^{144}$ The applicant did not sign this document and there was no evidence from the respondent that its provisions were drawn to his attention. Sachs J pointed out that the document was a standard form contract and contained fine print that was hard to read. The present author will now turn to the analysis of standard form contracts.

\subsection{Analysis of standard form contracts}

In discussing standard form contracts, Sachs J made the following points:

(1) Standard form contracts are drafted in advance by the suppliers of goods or services and presented to the consumers on a take-it-or-leave-it basis. ${ }^{145}$

(2) As it is impracticable for ordinary people in their daily commercial activities to enlist the advice of a lawyer, most consumers simply sign or accept the contract without knowing the full implications of their acts. ${ }^{146}$

(3) The consumer cannot be expected to shop around and wade through endless small print in endless standard form contracts. This would be beyond the expectations that could be held of any ordinary person who simply wished to get his or her car insured. ${ }^{147}$ In fact, the insured only looks for a reliable insurer that offers what he or she thinks are reasonable terms regarding cover and premiums. ${ }^{148}$ The potential purchaser of short-term insurance cannot be expected to consult a lawyer and seek legal advice on every term in the standard form contract. ${ }^{149}$ The cost of obtaining legal advice will be unreasonable in these circumstances.

In a business dealing with consumers, "lawyers devised printed contracts that purport to govern exclusively the business relationship between the parties". ${ }^{150}$ Standard form contracts are thus ordinarily the product, not of negotiations, but of the employment of legal terms by sellers of goods and services to serve their interests. ${ }^{151}$ They preserve the wisdom of their in-house lawyers concerning the best way in which to handle recurrent problems of negotiation and performance. ${ }^{152}$ As a result, standard form contracts protect the interest of the suppliers, to the detriment of the consumers.

Sachs $\mathrm{J}$ stated that the use of standard form contracts "often resembles an imposition of will rather than mutual consent to an agreement". ${ }^{153}$ They have therefore been described as contracts of adhesion. In reality, the consumer does not genuinely consent to the terms contained in standard form contracts which have not been read (or been expected to be read) by him or her. ${ }^{154}$ These terms are not even expected to be the subject of negotiation. As a result, they cannot be part of the contract.

Sachs J quoted Rakoff155 where he pointed out in an influential article that "freedom of contract has long been defined in terms of separation of the market, the state, private and public law; at its fullest reach, it is the doctrine of laissez faire". ${ }^{156} \mathrm{He}$ continues to argue that "to use such a framework to deal with contract of adhesion is to err both in valuing highly claim to freedom that is inapposite, and to overlook the elements of liberty that are actually at stake". 157 The use of contracts of adhesion enables firms to legislate in a substantially authoritarian manner without using the

\footnotetext{
143 Ibid.

144 Ibid para 134.

145 Ibid para 135.

146 Ibid para 136.

147 Ibid.

148 Ibid.

$149 \mathrm{lbid}$.

150 Ibid para 137.

151 Ibid.

152 Ibid.

153 Ibid para 138.See also PN Stoop "The current status of the enforceability of contractual exemption clauses for the exclusion of liability in the South African law of contract" (2008) 20 SA Merc LJ 496 - 497 where the author states that 'The content of standard-form contracts is usually fixed and determined unilaterally, and the other party then only has the choice of accepting the fixed contract terms in order to contract, so much so that freedom of contract (in the sense of a party's concluding a contract when, with whom and on the terms that he chooses) is only a theoretical freedom comprising the decision whether one wishes to contract.'

154 Barkuizen v Napier (note 1 above) para 168.

155 Rakoff (note 76 above) 1237.

156 Barkuizen v Napier (note 1 above) para 145.

157 Ibid para 145.
} 
appearance of authoritarian forms. ${ }^{158}$

Standard form contracts undermine, rather than support, the integrity of what was actually concluded between the parties. Sachs J warned that "they unilaterally introduce elements that were never in reality bargained for, and that had nothing to do with the actual bargain". 159 In fact, they induce automatism. Business people can request lawyers to scrutinise the fine print with professional lenses and advise accordingly, but ordinary consumers cannot be expected to do the same. ${ }^{160}$ In reality, the result is that much of the contract is "not a record of what was agreed upon but a superimposed construction favouring one side". ${ }^{161}$ This does not promote the spirit of openness recognised in our constitutional order.

After dealing with public policy in South African contract law, ${ }^{162}$ Sachs J examined guidance from international practice on standard form contracts. Collins stated that "one of the foremost general challenges for legal regulation of market during the $20^{\text {th }}$ century was the requirement to limit the advantages which business could obtain against consumers by deploying standard form contracts". 163 In this regard, Western countries, in the early nineteen seventies, enacted legislation to protect consumers. According to South African Law Reform Commission (SALRC), "such laws have been enacted in Denmark, Sweden, Norway, France, the Federal Republic of Germany, the Netherlands and Australia as well". ${ }^{164}$ A number of South American countries have also enacted legislation since 1990 to protect consumers against unfair contracts. ${ }^{165}$ These statutes were heavily influenced by the Mexican Consumer Protection Law of 1975 and the Brazilian Consumer Protection Code of 1990, as well as Spanish and French Consumer Protection Law. 166

In its research concerning the reviewability of unfair term in contracts, the SALRC concluded that "the common law as it was being applied was inadequate for providing appropriate remedies in relation to contractual terms that were unconscionable, oppressive or unreasonable". 167 It stated that, in modern contract law, "a balance had to be struck between the principle of freedom of contract, on the one hand, and the counter-principle of social control over private volition in the interest of public policy, on the other". ${ }^{168}$ According to the SALRC, "there was a need to legislate against contractual unfairness, unreasonableness, unconscionability or oppressiveness in all contractual phases, namely at the stage when the contract comes into being, when it is executed and when its terms are enforced". ${ }^{169}$ Naude also argues for a statutory intervention to protect freedom of contract. ${ }^{170} \mathrm{He}$ emphasises that South Africa needs legislation to deal with unfair contractual terms, particularly in the light of inherent limits of judicial control. ${ }^{171}$ Legislation can ensure real freedom of contracting parties in the standard form contracts.

Due to the role played by standard form contracts in commercial transactions, it makes sense to permit their use, but to control their content. ${ }^{172}$ Sachs J does not recognise a blanket acceptance of standard form terms, or their blanket rejection. He admits that there is a need for a principled approach, using objective criteria, consistent with deep principles of contract law and with sensitivity to the way in which economic power in public affairs should appropriately be regulated, to ensure standards of fairness in an open and democratic society. ${ }^{173} \mathrm{He}$ specifically calls for the examination of the tendency of the provision at issue and the extent to which, in the context of the contract as a whole, it vitiates standards of reasonable and fair dealing that the legal conviction of the community would regard as intrinsic to

\footnotetext{
158 Ibid para 145; Rakoff (note 76 above) 1237.

159 Barkuizen v Napier (note 1 above) para 155.

160 Ibid para 156.

161 Ibid para 156.

162 Ibid paras 158 - 161.

163 Ibid para 161. Collins The law of contract $3^{\text {rd }}$ ed. (1977) 2-3.

164 SALRC "Unreasonable Stipulations in Contracts and the Rectification of Contract" Project 47 (April 1998) para 1.44; Barkuizen v Napier (note 1 above) para 163.

165 Barkuizen v Napier (note 1 above) para 166.

166 Ibid para 166; SALRC Report (note 164 above) para 2.2.2.1.

167 Barkuizen v Napier (note 1 above) para 169.

168 Ibid para 170.

169 Ibid.

170 T Naude "Unfair contractual term legislation: the implications of why we need it for its formulation and application" (2006) 17 Stell LR 361, 366; J Lewis "Unfairness in South African contract law" (2003) 120 SALJ 330, 348.

171 Naude (note 170 above) 384.

172 Barkuizen v Napier (note 1 above) para 139.

173 Ibid para 146.
} 
appropriate business firm or consumer relationships in contemporary society. ${ }^{174}$ Sachs $\mathrm{J}$ observes that public policy has moved radically away from automatic application of standard form contracts towards a more balanced approach, in keeping in with constitutional values. ${ }^{175} \mathrm{He}$ concludes that public policy seeks to achieve the reconciliation of the interests of both parties to the contract on the basic of standards that acknowledge the public interest without unduly undermining the scope for individual volition. ${ }^{176}$ This approach may solve most of the problems or challenges experienced by consumers in standard form contracts.

Academic commentators supported the "need to ensure that courts refused on the grounds of public policy to enforce contract, or contractual terms, that were unfair or unconscionable". 177 Furthermore, "leading writers on contracts law commented on the unfairness of the manner in which standard form contracts operated". ${ }^{178}$ It is a mistake, however, to take academic views on the legal convictions of the community as actually constituting these convictions. ${ }^{179}$ Nevertheless, academic views play a persuasive role in judicial decisions.

Sachs J remarked that 'the bargain did not in reality contain at its heart a limitation of the rights it conferred'. ${ }^{180}$ The agreement simply covered the use to which the car could be put, the damage to be insured against and the premiums to be paid. ${ }^{181}$ The time-bar was contained in an ancillary clause buried in the dense standard form text of the added-on Lloyd's certificate of insurance. It was removed "from the heart of the contract, obscurely located in the fourth document of the bundle annexed to the particulars of the claim". ${ }^{182}$ The time-bar appeared "not to have been part of the actual bargain concluded and not to be a provision of the kind which a reasonable car owner renewing an insurance policy could be expected to read, let alone digest". ${ }^{183}$

Sachs $\mathrm{J}$ held that considerations of public policy animated by the Constitution dictated that the time-bar clause should not be enforced, and that the insured should not be deprived of his right to proceed with his claim on the merit. ${ }^{184}$ He was therefore of the view that the appeal be upheld and the special plea dismissed. This was a minority judgment and could not bind the court. However, the Consumer Protection Act strongly affects the terms and provisions of standard form contracts.

\section{The Impact of the Consumer Protection Act on Standard-Form Contracts}

The Consumer Protection Act (CPA) ${ }^{185}$ has a profound impact on the law of contract and, in particular, on the approach to standard form contracts. Some of the objectives of the Act are: "promoting fair business practices; protecting consumers from - unconscionable, unfair, unreasonable, unjust or otherwise improper trade practices; and deceptive, misleading, unfair or fraudulent conduct". ${ }^{186}$ Furthermore, it has the purpose to improve "consumer awareness and information and encourage possible and informed consumer choice and behaviour". ${ }^{187}$ In its preamble, it aims to "improve access to, and the quality of, information that is necessary so that consumers are able to make informed choices according to their individual wishes and needs". ${ }^{188}$ This may require the suppliers of goods or services to highlight and explain exemption clauses in the standard form contracts to the consumers, so that they can make informed decisions in their transactions. In addition, the CPA has the aim to "protect the interests of all consumers, ensure accessible, transparent and efficient redress for consumers who are subjected to abuse or exploitation in the

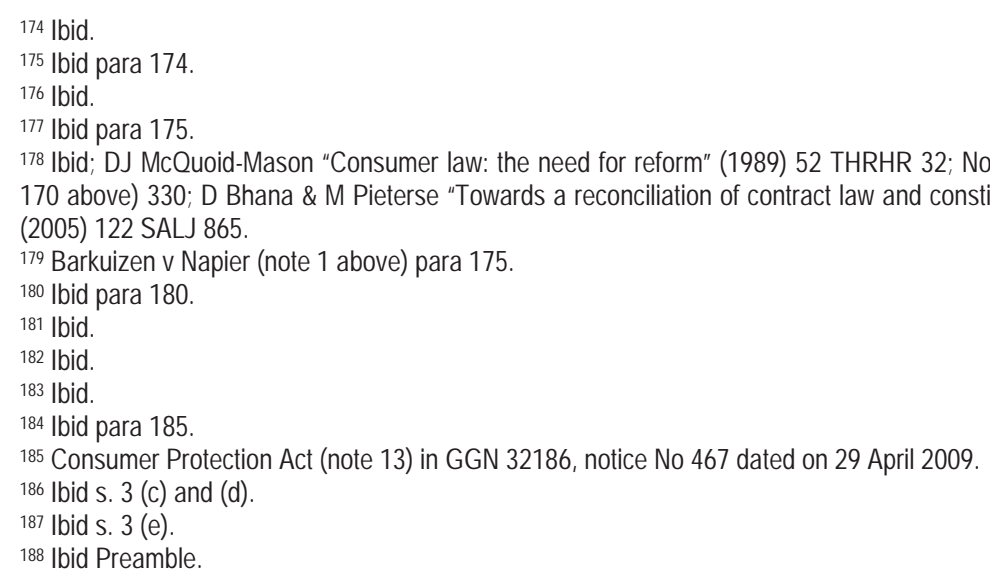


marketplace". ${ }^{189}$ Therefore consumers will be advised to act according to the terms of the contract.

There is provision in the CPA for a right to fair and honest dealing. Unconscionable conduct is prohibited. It is provided that "a supplier or an agent of the supplier of goods or services must not use physical force against a consumer, coercion, undue influence, pressure, duress or harassment, unfair tactics or any other similar conduct, in his or her activities". ${ }^{190}$ In addition, "it is unconscionable for a supplier knowingly to take advantage of the fact that a consumer was substantially unable to protect the consumer's own interests because of physical or mental disability, illiteracy, ignorance, inability to understand the language of an agreement, or any other similar factor." 191 This provision prevents the supplier of goods or services from using terms that are not understandable by the consumers, in standard form contracts. He or she may not profit from the ignorance or weakness of the consumers in order to exclude an advantage that is usually available to the consumer. It is also prohibited to use false, misleading or deceptive representations. ${ }^{192}$

Section 48 prohibits unfair, unreasonable or unjust contract terms. A supplier must not offer to supply, supply, enter into an agreement to supply, any goods or services - at a price that is unfair, unreasonable or unjust; or on terms that are unfair, unreasonable or unjust. ${ }^{193} \mathrm{He}$ or she must not market any goods or services, or negotiate, enter into or administer a transaction or an agreement for the supply of any goods or services, in a manner that is unfair, unreasonable or unjust. ${ }^{194} \mathrm{~A}$ supplier must not require a consumer or other person to whom many goods or services are supplied at the direction of the consumer - to waive any rights; assume any obligation, or waive any liability of the supplier, on terms that are unfair, unreasonable or unjust, or impose any such terms as a condition of entering into a transaction. ${ }^{195}$ In a standard form contract, the supplier is not able to require the consumer to waive any rights, or waive any liability on unreasonable terms. Furthermore, such a contract may also be challenged on the ground that "it is excessively one-sided in favour of any other person other than the consumer or other persons to whom goods or services are to be supplied". 196 This section has a huge impact on current standard form contracts, as they usually favour the supplier, to the detriment of the consumer.

Certain terms and conditions must be communicated between the parties. ${ }^{197}$ Section 49 provides that any notice to the consumer or provision of a consumer agreement that purports to limit, in any way, the risk or liability of the supplier or any other person; constitute an assumption of risk or liability by the consumer; impose an obligation on the consumer to indemnify the supplier or any other person for any cause; or be an acknowledgment of any fact by the consumer, must be drawn to the attention of the consumer in an adequate manner and form. ${ }^{198}$ This means that a condition or notice must be written in a plain language. ${ }^{199}$ The fact, nature and effect of the provision or notice must be drawn to the attention of the consumer in a conspicuous manner and form that is likely to attract the attention of an ordinarily alert consumer, having regard to the circumstances. ${ }^{200}$ The notice or condition must be communicated to the consumer before the time at which he or she "enters into the transaction or agreement, begins to engage in the activity, or enters or gains access to the facility; or is required or expected to offer consideration for the transaction or agreement."201 Finally, the consumer must be given adequate opportunity in the circumstances to receive and comprehend the provision or notice. $^{202}$

Section 51 provides for prohibited transactions, agreements, terms or conditions. For instance, "a supplier must not make a transaction or agreement subject to any term or condition if its general purpose or effect is to mislead or deceive the consumer; or deceive the purpose and policy of the Consumer Protection Act." 203 Consequently, in a standard form contract, the supplier must not use the terms or any other condition that may mislead the consumer.

The criticism of the CPA is that it only applies to the transactions between consumers and suppliers of goods and

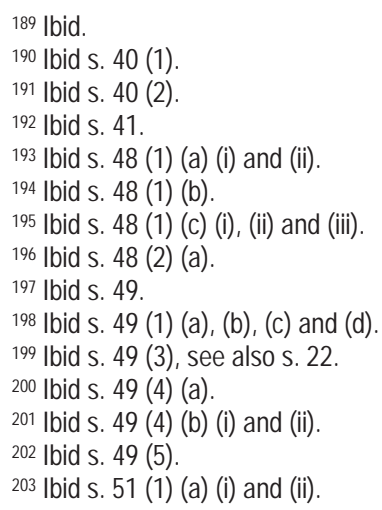


services. As a result, it may not be applied to contracts that do not involve consumers and suppliers. For example, "it does not apply to employment contracts, credit agreement, and transactions where the consumer is the state". ${ }^{204}$ Although it will contribute significantly to ensure that standard form contracts are fair, just and reasonable between the contracting parties, other kinds of contracts will be unaffected. For instance, "the Act does not provide a blanket exclusion to the insurance industry from the ambit of the Act". ${ }^{205}$ Insurance companies needs to review the provisions in the insurance policies and adjust them to the consumer protection measures. ${ }^{206}$ Other measures must therefore be put in place to avoid the abuse of bargaining power by the strong party, to the detriment of the weak party.

Dinnie argues that "the prohibition against unfair, unreasonable or unjust contract terms will be problematic and could give scope to the challenge of many policy terms and provisions". ${ }^{207}$ As a result, Judin "strongly recommended that all manufacturers, suppliers, and service providers sit with their insurers to draft the terms and provisions of their insurance policies carefully, so as to ensure"208 that they comply with the CPA. Furthermore, "the day of excluding all warranties, disclaiming all liabilities and leaving consumers without any remedies are becoming to an end". ${ }^{209}$ The CPA will have a significant impact on the terms and provisions of standard form contracts. The Act may contribute to ensuring true consensus between contracting parties.

\section{Conclusion and Recommendation}

Standard form contracts are drafted in advance by the supplier of goods or services and presented to the consumer on a take-it-or-leave-it basis. They eliminate the opportunity for arm's length negotiation between contracting parties. The consumer's only choice is to adhere to, or refuse to adhere to, the terms of the standard form contract. This contract is used in daily commercial life and has various advantages for both contracting parties. Such advantages include cost saving, certainty, uniformity and easy altering. They allow the supplier to perform massive transactions on similar terms. Such contracts provide certainty in legal relations, save the time, effort and money for both suppliers and consumers.

There are some inherent disadvantages in standard form contracts as they are one-sided against the consumers and impose unfair terms on the contracting party. Consumers are not consulted or represented in drafting standard form contracts. As a result, they are not easy to understand and the consumer usually signs the contract without appreciating its content and legal implications. The contract does not, therefore, represent a genuine agreement between the contracting parties. The consumer has no control over the imposition of unfair terms that deprive him or her of reasonable rights of compensation, or otherwise oust the protection of common law. However, standard form contracts are binding and must be honoured by the contracting parties.

Public policy can be used to rescue the person from greatly unfair obligations that arise from the contracts. Common law does not recognise contracts that are contrary to public policy. Courts do not hesitate to declare contracts contrary to public policy when the occasion so demands. Public policy derives from the Constitution and the fundamental values it enshrines. It is determined according to the constitutional values, especially the Bill of Rights. Consequently, a contractual term that violates the Constitution is, by definition, contrary to public policy and therefore unenforceable. ${ }^{210} \mathrm{It}$ follows that a standard form contract, the terms of which are contrary to the Constitution, is invalid and unenforceable. This occurs even if the parties have freely and voluntarily agreed to the conclusion of their contracts. Sachs J has recommended the use of standard form contracts but warned that they should be carefully scrutinised to avoid the abuse of contractual freedom.

The CPA has a significant impact on the law of contract, especially standard form contracts. It imposes a duty on the suppliers to provide necessary information so that consumers are able to make informed choices, in order to satisfy their wishes and needs. The consumer has a right to fair and honest dealing. There is a prohibition of unfair,

204 J Maphosa 'Manufacturers and suppliers beware: consumer law' (2009) 9 Without Prejudice 36, 36. Available at http://reference.sabinet.co.za/webx/access/electronic_journals/jb_prej/jb_prej_v9_n5_a20.pdf (accessed on 14 December 2012).

205 D Dinnie 'Consumer Protection Act could waylay insurers: the Act will affect insurers both directly and indirectly: general insurance' (2009) 3 Enterprise Risk 6, 6. Available at http://search.sabinet.co.za/WebZ/Authorize?sessionid=0\&bad=ejour/ejour_badsearch.html \&portal=ejournal\&style=ejour\&next=images/ejour/sh_eprise/sh_eprise_v3_n6_a3.pdf\&clientid=5800 (accessed on 14 December 2012). 206 Ibid 6.

$207 \mathrm{lbid} 7$

${ }^{208}$ M Judin 'The Consumer Protection Act : legal update' (2007) 1 Enterprise Risk 22, 23. Available at http://search.sabinet.co.za WebZ/Authorize?sessionid=0\&bad=ejour/ejour_badsearch.html\&portal=ejournal\&style=ejour\&next=images/ejour/images/ejour/sh_epris e/sh_eprise_v1_n4_a8.pdf\&clientid=5800 (accessed on 12 December 2012).

209 lbid 23.

${ }^{210}$ Barkuizen v Napier (note 1 above) para 29. 
unreasonable or unjust contractual terms. The supplier has a duty to draw the attention of the consumer to the exemption clauses or other contractual terms that oust common law protection. The CPA only applies to transactions between suppliers and consumers.

It is submitted that the prohibition of unfair, unreasonable or unjust contract terms should apply to every contract. Parliament should intervene and enact legislation to prevent the abuse of freedom of contract by the strong party, to the detriment of the other contracting party. This will assist contracting parties to comply with public policy and respect the fundamental values, especially the Bill of Rights, enshrined in the Constitution. It is recommended that suppliers should provide a model standard form contract to consumers and allow them sufficient time to ascertain the implication of the contractual terms before entering into a transaction. This will allow consumers to ensure the consequences of failure to comply with the standard form contracts and decide to contract with an informed consent.

\section{References}

Aronstam, P Consumer protection, freedom of contract and the law Cape Town: Juta (1979) Atiyah, PS The rise and fall of freedom of contract Cape Town: Clarendon Press (1979)

Christie, RH The law of contract in South Africa $5^{\text {th }}$ ed. Durban: LexisNexis Butterworths (2006)

Collins The law of contract 3 rd ed. Cape Town: Juta (1977)

Kahn, E et al Contract and mercantile law a source book 2nd ed. Vol. 1 Cape Town: Juta (1988)

Van der Merwe, $S$ et al Contract general principles $3^{\text {rd }}$ ed. Cape Town: Stellenbosch University (2007)

Yates, D Exclusions clauses in contracts $2^{\text {nd }}$ ed. London: Sweet \& Maxwell (1982)

Alheit, $\mathrm{K}$ "Contractual liability arising from the use of computer software: notes on the different positions of parties in Anglo-American law and South African law" (2000) 23 CILSA 26

Aronstam, P "Exemption clauses in contracts: a new approach for South African courts" (1977) 94 SALJ 55

Bhana, D \& Pieterse, M "Towards a reconciliation of contract law and constitutional values: Brisley and Afrox revisited" (2005) 122 SALJ 865

Brand, FDJ "The role of good faith, equity and fairness in the South African law of contract: the influence of the common law and constitution" (2009) 126 SALJ 70

Bright, CH Contracts of adhesion and exemption clauses" (1967) 41 Australian LJ 261

Collins, H "Legal responses to the standard form contract of employment" (2007) 36 ILJ 2

Cornelius, S "The writing is on the wall for small print" (2001) 4 TSAR 793

Eiselen, S \& Bergenthal, SK "The battle of forms: a comparative analysis" (2006) 39 CILSA 214

Grunfeld, C "Reform in the law of contract" (1961) 24 Modern LR 62

Hahlo, HR "Buying a new motor car - an object lesson in standard form contracts" (1956) 73 SALJ 443

Hahlo, HR "Unfair contractual terms in civil law system" (1981) 98 SALJ 70

Harker, JR "Imposed terms in standard form contracts" (1981) 98 SALJ 15

Hopkins, K "Insurance policies and the Bill of Rights: rethinking the sanctity of contract paradigm" (2002) 119 SALJ 155

Hopkins, K "Standard-form contracts and the evolving idea of private law justice: a case of democratic capitalist justice versus natural justice" (2003) 1 TSAR 150

Kessler, F "Contracts of adhesion - some thoughts about freedom of contract" (1943) 43 Columbia LR 629

Kruger, M "The role of public policy in the law of contract, revisited" (2011) 128 SALJ 712

Lewis, C "Caveat subscriptor and the doctrine of justus error" (1987) 104 SALJ 371

Lewis, J "Fairness in South African law of contract" (2003) 120 SALJ 330

Louw, A "Employment based on a fiction: evaluating the legitimacy of traditional notions of contract in their application to an atypical employment relationship" (2007) 28 Obiter 187

McQuoid-Mason, DJ "Consumer law: the need for reform" (1989) 52 THRHR 32

Naude, T "Unfair contractual term legislation: the implications of why we need it for its formulation and application" (2006) 17 Stell LR 361

Nortje, M "'Unexpected terms' and caveat subscriptor" (2011) 128 SALJ 741

Nortje, M "Of reliance, self-reliance and caveat subscriptor" (2012) 129 SALJ 132

Pretorius, CJ "Mistake and suretyship: avoiding the spectre of Brink v Humphries \& Jewell (Pty) Ltd" 2009 Obiter 763

Pretorius, CJ "The basis and underpinnings of the caveat subscriptor rule" 2008 THRHR 660

Rakoff, TD "Contracts of adhesion: an essay in reconstruction" (1983) 96 Harvard LR 1173

Sales, HB "Standard form contracts" (1953) 16 Modern LR 318

Sharrock, RD "Judicial control of unfair contract terms: the implications of Consumer Protection Act" (2010) 22 SA Merc LJ 295

Slawson, WD "Standard form contracts and democratic control of lawmaking power" (1971) 84 Harvard LR 529

Stoop, PN "The current status of the enforceability of contractual exemption clauses for the exclusion of liability in the South African law of contract" (2008) 20 SA Merc LJ 496

Sutherland, PJ "Ensuring contractual fairness in consumer contracts after Barkuizen v Napier 20075 SA 323 (CC) Part 2" (2009) 20 
Stell LR 50

Sutherland, PJ "Ensuring contractual fairness in consumer contracts after Barkuizen v Napier 20075 SA 323 (CC) Part 1" (2008) 19 Stell LR 390

Turpin, CC "Contract and imposed terms" (1956) 73 SALJ 144

Wilson, NS "Freedom of contract and adhesion contracts" (1965) 14 ICLQ 172

Woolfrey, DJ "Consumer protection - a new jurisprudence in South Africa" (1989 - 1990) 11 Obiter 109

Constitution of the Republic of South Africa Act 108 of 1996

Consumer Protection Act 68 of 2008

Afrox Healthcare (Bpk) v Strydom 20026 SA 21 (SCA)

Barkuizen v Napier 20075 SA 323 (CC)

Bhikhagee v Southern Aviation (Pty) Ltd 19494 SA 105 (E)

Brisley v Drotsky 20024 SA 1 (SCA)

Burger v Central South African Railways 1903 TS 571

Central South African Railways v Mc Laren 1903 TS 727

Cinema City Pty Ltd v Morgenstern Family Estates Pty Ltd and Others 19801 SA 796 (A)

Eerste Nasionale Bank van Suidelike Afrika Bpk v Saayman NO 19974 SA 302 (SCA)

Frocks Ltd v Dent and Goodwin (Pty) Ltd 19502 SA 717 (C)

Goedhals v Massey-Harris \& Co 1939 EDL 314

George v Fairmead (Pty) Ltd 19582 SA 465 (A)

Glen Comeragh (Pty) Ltd v Calibri (Pty) Ltd 19793 SA 210 (T)

Jajbhay v Cassiem 1939 AD 537

Jordaan v Trollip 1960 PH A25 (T)

Joubert v Enslin 1910 AD 6

Linstrom v Venter 19571 SA 125 (SWA)

Magna Alloys and Research SA (Pty) Ltd v Ellis 19844 SA

Mathole v Mathole 19511 SA 256 (T)

Minor Shipping (Pty) Ltd v Treger Golf and Sports (Pty) Ltd 19772 SA 709 (W)

Napier v Barkuizen 20064 SA 1 (SCA)

Peard v Rennie \& Sons (1895) 16 NLR 175

Saskin (Pty) Ltd) v Beukes 19891 SA 1 (A)

Smith v Carson 1916 EDL 26

Tjollo Ateljees (Eins) Bpk v Small 19491 SA 856 (A)

W J Lineveldt (Edms) Bpk v Immelman 19802 SA 964 (O)

Wells v South African Alumenite Co 1927 AD 69

Western Bank Ltd v Sparta Construction Co 19751 SA 839 (W)

Fender v St John - Mildmay 19933 All ER 402

Printing and Numerical Registration Co v Sampson [1897] LR 19 Eq 462

Olsen v Standafolt 19832 SA 668 (ZS)

SALRC "Unreasonable Stipulations in Contracts and the Rectification of Contract" Protect 47 (April 1998)

Dinnie, D "Consumer Protection Act could waylay insurers: the Act will affect insurers both directly and indirectly: general insurance" (2009) 3 Enterprise Risk 6, 6. Available at

http://search.sabinet.co.za/WebZ/Authorize?sessionid=0\&bad=ejour/ejour_badsearch.html\&portal=ejournal\&style=ejour\&next=images/ej our/sh_eprise/sh_eprise_v3_n6_a3.pdf\&clientid=5800 (accessed on 14 December 2012)

Judin, M "The Consumer Protection Act: legal update" (2007) 1 Enterprise Risk 22, 23. Available at http://search.sabinet.co.za/WebZ/Authorize?sessionid=0\&bad=ejour/ejour_badsearch.html\&portal=ejournal\&style=ejour\&next=im ages/ejour/images/ejour/sh_eprise/sh_eprise_v1_n4_a8.pdf\&clientid=5800 (accessed on 12 December 2012)

Maphosa, J "Manufacturers and suppliers beware: consumer law" (2009) 9 Without Prejudice 36, 36. Available at http://reference.sabinet.co.za/webx/access/electronic_journals/jb_prej/jb_prej_v9_n5_a20.pdf (accessed on 14 December 2012). 